\title{
Fishes of the genus Olyra M cClelland (Teleostei: Bagridae) from Indo-Bhutan hill streams of Assam, India
}

\author{
Sewali Pathak ${ }^{1 *}$, M rigendra M . G oswami² and N ripendra Nath Sharma ${ }^{3}$ \\ 'Department of Zoology, Bijni College, Bijni, Chirang-783390 (Assam), INDIA \\ ${ }^{2}$ Department of Zoology, Gauhati University, Guwahati-781014 (Assam), INDIA \\ ${ }^{3}$ Department of Zoology (Ex-HOD), Bajali College, Pathsala, Pin-781346, Barpeta (Assam), INDIA \\ *Corresponding author. E-mail: sewalip@gmail.com
}

Received: J une 22, 2013; Revised received: November 26, 2013; Accepted:D ecember 15, 2013

\begin{abstract}
The type specimens described in this communication are collected from two hill streams, Kanamakra and Langkhar flowing from the Bhutan foothills of the Himalaya through Amguri and Amteka respectively in the Indo-

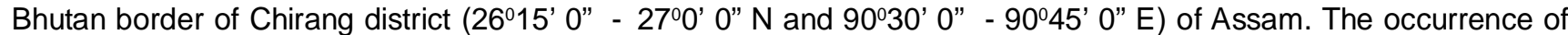
three catfishes species of the genus Olyra, of which Olyra horae is recorded as a new report from the type locality of Assam. The taxonomic variables of 0 . horae are compared with other two species namely, 0 . kempi and 0 . longicaudata. The 0 . horae is distinguished from the other two congeners in having the caudal fin forked but not high, upper lobe slightly elongated with 10 rays and lower lobe with 9 rays. It can also be distinguished in having the higher range of the caudal peduncle length (16.9 - $20.0 \% \mathrm{SL}$ ), pre-anal length $(60.1-71.4 \% \mathrm{SL})$, head width (81.3 $-81.6 \% \mathrm{HL})$ and the lower range of snout length $(21.7-24.3 \% \mathrm{HL})$, outer mandibular barbel length $(55.7-57.3 \%$ $\mathrm{HL}$ ) in comparison to the other two congeners.
\end{abstract}

Keywords: Brahmaputra drainage, Indo-Bhutan streams, Olyra catfish species, Siluriformes

\section{INTRODUCTION}

Embracing two hill streams, Kanamakra and Langkhar, the district Chirang $\left(26^{\circ} 15^{\prime} 0^{\prime \prime}-27^{\circ} 0^{\prime} 0\right.$ "' $\mathrm{N}$ and $90^{\circ} 30^{\prime} 0^{\prime \prime}$ $90^{\circ} 45^{\prime} 0$ " E) is situated in the lower Assam Zone near Manas National Park at the northern bank of the River Brahmaputra. The occurrence of three species of the catfish genus Olyra from Langkhar and Kanamakra hillstreams at the place of Amteka and Amguri respectively is recorded at about $42 \mathrm{~km}$ and $30 \mathrm{~km}$ north- west of Bijni suburban town of the district. Two species namely, 0 . kempi and 0 . Iongicaudata collected from both the streams were reported earlier while 0 . horae constitutes a new occurrence record in the type locality of Assam. The taxonomic details of all three Olyra species (holotypes) have been worked out to describe their taxonomic status. The genus Olyra McClelland, 1842 presently contains only five valid species as the members of small- bodied elongate catfishes thriving in rheophilic streams and fast moving rivers of Nepal, Myanmar, Bangladesh, Darjeeling Himalayas of North Bengal and the states of North-East India like Arunachal Pradesh, Meghalaya, Manipur, Nagaland and Assam. Three species namely, 0 . burmanicus, 0 . Iongicaudata, and 0 . horae of the genus Olyra were described by Day (1878) from the Khasia hills (presently Meghalaya) and British Burma. Menon (1974) described the genus O lyra as monotypic one for 0 . longicaudata while all other species like 0. burmanicus (Day, 1878), 0. elongata Gunther, 1883, 0. kempi Chaudhuri, 1912 and Amblyceps horai Prasad \& Mukerji, 1929 were considered as the synonyms of it. However, Talwar and Jhingran (1991) separated the species 0 . burmanicus, 0 . Iongicaudata and 0 . horae while 0 . kempi was placed as a synonym of O. Iongicaudata. On the other hand, Jayaram (1999) referred to four different species of the genus, the two of which namely 0 . Iongicaudata and 0 . kempi are from Indian region, and suggested further study for inclusion of 0 . kempi under the synonyms of 0 . Iongicaudata. Sen (1985) mentioned four species of Olyra like 0 leticeps, 0 . horae, 0 . longicaudata and 0 . kempi with their distinguishing characteristics. Nath and Dey (2000) has given the systematic account of only 0 . longicaudata reported from Arunachal Pradesh. Mo (1991) included the genus to family Bagridae based on some synapomorphies. During ichthyological survey in the foothill streams of Chirang District, the present genera are reported as the type locality of Assam along with the description of taxonomic significance.

\section{MATERIALS AND METHODS}

Morphometric measurements for 27 parameters were done by using Mitutoyo absolute digimatic dial calipers made on the left side of the specimens following $\mathrm{Ng}$ and 
Kottelat (1998). The data were recorded to tenths of a millimeter. Parameters related to the subunits of the head are presented as the ratio of head length (HL). The other morphometric parameters of the body parts are given as proportions of standard length (SL). The fin rays were counted under a computer based binocular stereo-zoom microscope (Leica ATC 2000) using transmitted light. Materials examined in this study are deposited to Gauhati University Zoological Museum (GUZM). The paratypes of Olyra specimen are used from Manipur University Fish Museum (MUFM) and record of Zoological Survey of India (ZSI), Kolkata. Valid name of genera and latest systematic status of species were adopted from California Academy of Sciences web site www.calacademy.org/ catalogue. Conservation status of the species was assigned by Conservation Assessment and Management Plan (CAMP) and IUCN criteria (Molur and Walker, 1998).

\section{RESULTS}

Taxonomic description of the species

Olyra horae (Prasad and M ukerji, 1929)

$M$ aterial examined: Holotype: GUZM- 8/0130, $85.95 \mathrm{~mm}$

SL, Kanamakra stream (Amguri-30 km north from Bijni town) in Chirang district $\left(26^{\circ} 15^{\prime} 0^{\prime \prime}-27^{\circ} 0^{\prime} 0^{\prime \prime} \mathrm{N}\right.$ and $90^{\circ} 30^{\prime}$ 0" - 9045' 0" E) of Assam, 2012.

Paratypes: ZSI F 10854/1, 1, 67.4 mm SL; Indawgyi Lake along its western shore near Loimon village, Myitkyina District of Upper Myanmar (Burma); GUZM-8/0132 (3), 70 mm SL-84 mm SL; Langkhar and Kanamakra hill stream (Amteka and Amguri - $42 \mathrm{~km}$ and $30 \mathrm{~km}$ north from Bijni town) in Chirang district $\left(26^{\circ} 15^{\prime} 0^{\prime \prime}-27^{\circ} 0^{\prime} 0^{\prime \prime} \mathrm{N}\right.$ and 90 $30^{\circ}$ 0" - 90045' 0" E) of Assam, 2012.

Diagnosis: Anal fin with 10-11 branched rays, adipose fin low, jaws of equal length, caudal fin deeply forked and upper lobe slightly longer than lower lobe, maxillary barbels reach base of pectoral fin, head width 81.33 $81.67 \% \mathrm{HL}$, head depth at occiput $54.42-56.77 \% \mathrm{HL}$, eye diameter $9.67-11.53 \% \mathrm{HL}$, inter-orbital space 28.57 $30 \% \mathrm{HL}$, snout length $21.76-24.38 \% \mathrm{HL}$, body depth 9.30 - $10 \%$ SL, caudal peduncle length 16.90 - $20 \%$ SL, head length 17.85 - $21 \%$ SL (Table 1).

Description: Body elongated, flattened in pre-pelvic region and compressed behind, head small and depressed, snout short, mouth anterior and narrow, eyes small, gill openings wide, barbel 4 pairs and maxillary barbel reach up to pectoral fin base, Rayed dorsal without spine,
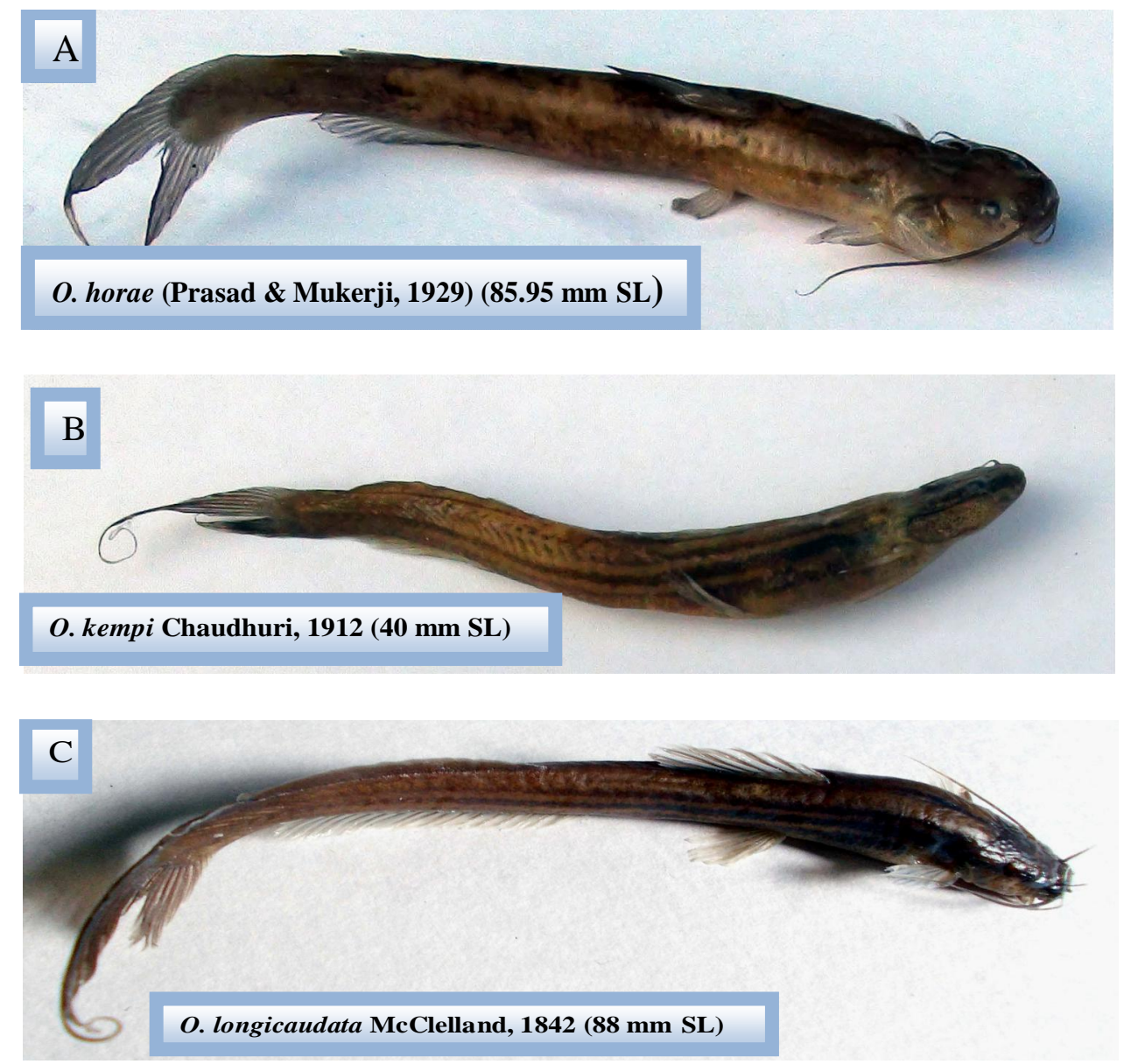

Fig. 1. Showing of Olyra species (holotype) in the study area (A) 0 .horae, (B) 0 . kempi, (C) 0 . Iongicaudata 
Table 1. Biometric data of three species of the genus Olyra (holotype and paratypes)

\begin{tabular}{|c|c|c|c|c|c|c|}
\hline & \multicolumn{2}{|c|}{ Olyra horae } & \multicolumn{2}{|c|}{ Olyra kempi } & \multicolumn{2}{|c|}{ Olyra longicaudata } \\
\hline & $\begin{array}{l}\text { Range } \\
(\mathrm{mm})\end{array}$ & M ean \pm SD & Range (mm) & M ean \pm SD & $\begin{array}{l}\text { Range } \\
(\mathrm{mm})\end{array}$ & M ean $\pm S D$ \\
\hline \multicolumn{7}{|l|}{$\% \mathrm{SL}$} \\
\hline Body depth & $9.3-10.0$ & $9.7 \pm 0.60$ & $11.0-11.5$ & $11.2 \pm 0.29$ & $9.7-10.2$ & $9.9 \pm 0.27$ \\
\hline Head length & $17.8-21.0$ & $18.9 \pm 1.76$ & $17.1-20.0$ & $18.4 \pm 1.50$ & $15.3-17.6$ & $16.1 \pm 1.32$ \\
\hline Caudal peduncle length & $16.9-20.0$ & $18.0 \pm 1.69$ & $8.8-13.6$ & $11.3 \pm 2.38$ & $14.0-16.7$ & $15.1 \pm 1.43$ \\
\hline Caudal peduncle depth & $7.2-8.4$ & $7.7 \pm 0.58$ & $6.8-7.1$ & $6.9 \pm 0.11$ & $7.5-7.8$ & $7.7 \pm 0.14$ \\
\hline $\begin{array}{l}\text { Dorsal to-Adipose } \\
\text { distance }\end{array}$ & $28.1-32.8$ & $29.8 \pm 2.63$ & $16.7-18.4$ & $17.4 \pm 0.89$ & $29.1-30.3$ & $29.8 \pm 0.61$ \\
\hline Dorsal fin base length & $9.4-11.1$ & $10.0 \pm 0.94$ & $11.1-11.7$ & $11.4 \pm 0.27$ & $10.2-10.7$ & $10.4 \pm 0.28$ \\
\hline Dorsal fin length & $5.1-6.0$ & $5.4 \pm 0.47$ & $6.9-9.2$ & $7.7 \pm 1.29$ & $7.1-7.9$ & $7.4 \pm 0.43$ \\
\hline Adipose fin base length & $8.9-10.0$ & $9.3 \pm 0.49$ & $25.0-26.5$ & $25.9 \pm 0.64$ & $8.1-9.9$ & $8.8 \pm 0.36$ \\
\hline Pectoral fin length & $9.28-10.0$ & $9.5 \pm 0.41$ & $9.3-10.8$ & $10.1 \pm 0.76$ & $8.1-8.7$ & $8.5 \pm 0.34$ \\
\hline Pelvic fin length & $10.5-12.5$ & $11.5 \pm 1.15$ & $10.9-12.9$ & $11.6 \pm 1.09$ & $10.2-10.8$ & $10.5 \pm 0.30$ \\
\hline Anal fin length & $30.1-35.7$ & $32.0 \pm 3.15$ & $31.1-33.7$ & $32.5 \pm 1.34$ & $28.7-32.0$ & $29.9 \pm 1.83$ \\
\hline Caudal fin length & $30.9-37.1$ & $33.0 \pm 3.55$ & $28.8-35.1$ & $31.9 \pm 3.15$ & $37.5-43.8$ & $40.3 \pm 3.21$ \\
\hline Pre dorsal length & $35.6-42.8$ & $38.2 \pm 3.99$ & $33.5-36.3$ & $35.2 \pm 1.50$ & $35.0-36.6$ & $35.9 \pm 0.85$ \\
\hline Pre pelvic length & $39.2-45.7$ & $41.4 \pm 3.72$ & $38.9-44.4$ & $41.2 \pm 2.83$ & $36.6-38.6$ & $37.4 \pm 1.05$ \\
\hline Pre anal length & $60.1-71.4$ & $63.9 \pm 6.44$ & $58.1-61.9$ & $59.7 \pm 2.00$ & $52.0-54.2$ & $53.1 \pm 1.07$ \\
\hline $\begin{array}{l}\text { Post adipose length } \\
\% H L\end{array}$ & $17.9-21.3$ & $19.2 \pm 1.83$ & $9.4-10.3$ & $9.8 \pm 0.44$ & $16.8-17.6$ & $17.2 \pm 0.37$ \\
\hline Head depth & $54.4-56.7$ & $55.5 \pm 1.18$ & $40.3-50.2$ & $46.6 \pm 5.46$ & $49.6-55.8$ & $52.7 \pm 3.13$ \\
\hline Head & $81.3-81.6$ & $81.5 \pm 0.18$ & $50.2-73.5$ & $62.1 \pm 11.64$ & $73.9-75.0$ & $74.5 \pm 0.55$ \\
\hline Snout & $21.7-24.3$ & $23.3 \pm 1.41$ & $22.1-29.0$ & $25.2 \pm 3.47$ & $26.4-33.2$ & $30.0 \pm 3.41$ \\
\hline Eye diameter & $9.6-10.2$ & $9.9 \pm 0.26$ & $11.3-14.7$ & $12.7 \pm 1.73$ & $8.4-11.0$ & $9.8 \pm 1.35$ \\
\hline Inter orbital dist & $28.5-30.0$ & $29.2 \pm 0.71$ & $24.0-29.0$ & $26.3 \pm 2.52$ & $27.0-31.2$ & $29.2 \pm 2.13$ \\
\hline Wide of gape of mouth & $36.0-38.7$ & $37.2 \pm 1.33$ & $39.4-40.8$ & $40.1 \pm 2.36$ & $33.4-39.2$ & $36.0 \pm 2.93$ \\
\hline Inter nostril distance & $27.2-29.6$ & $28.7 \pm 1.33$ & $28.3-36.7$ & $32.9 \pm 4.28$ & $25.8-27.5$ & $26.4 \pm 0.90$ \\
\hline Nasal barbel length & $33.2-34.0$ & $33.7 \pm 0.45$ & $28.3-36.7$ & $33.3 \pm 4.47$ & $38.5-45.8$ & $42.7 \pm 3.76$ \\
\hline Maxillary barbel length & $136.0-145$ & $140.3 \pm 13.50$ & $135.8-145.1$ & $140.1 \pm 12.90$ & $127.2-148.7$ & $138.7 \pm 10.81$ \\
\hline $\begin{array}{l}\text { Inner mandibular barbel } \\
\text { length }\end{array}$ & $40.8-43.2$ & $41.7 \pm 1.26$ & $46.2-59.3$ & $52.4 \pm 6.56$ & $37.2-45.0$ & $41.6 \pm 4.00$ \\
\hline $\begin{array}{l}\text { Outer mandibular barbel } \\
\text { length }\end{array}$ & $55.7-57.3$ & $56.5 \pm 0.77$ & $55.6-71.5$ & $62.9 \pm 8.02$ & $64.4-77.6$ & $71.4 \pm 6.61$ \\
\hline
\end{tabular}

adipose fin free and short and differentiating from the description of other authors, caudal fin forked, upper lobe slightly longer than lower, skin smooth without strips, body colour dusky white, ventral dull white, lateral line distinct, branchiostegal rays 6 , dorsal with one unbranched and five branched rays, pectoral 5 soft rays with a serrated spine, pelvic 6 soft rays, anal with 10615 branched rays, and caudal with 19 principal rays (Fig.1 A).

Distribution: Meghalaya state, Burma: Irrawady River and newly recorded here from Kanamakra and Langkhar hill stream in Chirang district of Assam, the Indo-Bhutan boarder along Manas National park (Fig.2) of Assam, India. The O lyra horae was collected from clear, shallow, moderately flowing hill stream with sandy bottom intercepted by pebbles.

IUCN status: Data Deficient (DD)

Olyra kempi Chaudhuri, 1912

M aterial examined: Holotype: GUZM- 8/0136, $40 \mathrm{~mm} \mathrm{SL}$, Kanamakra hill stream (Amguri- $30 \mathrm{~km}$ north from Bijni town) in Chirang district (26015' $0^{\prime \prime}-27^{\circ} 0^{\prime} 0^{\prime \prime} \mathrm{N}$ and 90 $30^{\prime}$ 0" - 90045' 0" E) of Assam, 2012

Paratypes: ZSI F 5387/1 (1), $40 \mathrm{~mm}$ SL, Records of the Indian Museum (ZSI, Calcutta) v. 7 (pt 5), Mangaldai, Assam-Bhutan Frontier, India; MUMF-14098-14100 (3); GUZM- 8/0137 (1), 47.26 mm SL, Kanamakra hill stream (Amguri-30 km north from Bijni town); GUZM- 8/0138 (1), $52.80 \mathrm{~mm} \mathrm{SL}$, Langkhar hill stream (Amteka- $42 \mathrm{~km}$ north from Bijni town) in Chirang district (26015' 0" - 2700' 0" $\mathrm{N}$ and 90030' 0" - 90'45' 0" E) of Assam, 2012 
Diagnosis: Anal fin with vii,14 rays, caudal fin with 16 rays, jaws of equal length, pelvic fin extending vertically through to beyond half length of distance between ventral and anal fin, body brownish with three longitudinal bands, two on side of lateral line, posterior end of adipose fin anterior to vertical level of posterior end of anal fin base, caudal fin forked with elongate upper lobe, maxillary pair of barbel reaching the base of pectoral fin, maximum head width 50.24 - $73.52 \%$ HL, head depth 40.37 - 50.24 $\% \mathrm{HL}$, eye diameter 11.32 - $12.50 \% \mathrm{HL}$, inter-orbital space $24.05-29.04 \%$ HL, snout length $22.16-29.04 \% \mathrm{HL}$ body depth $11-11.55 \%$ SL, caudal peduncle length 8.88 - $13.64 \%$ SL, head length 17.14 - $20.07 \%$ SL (Table 1).

Description: Body elongated, slender, flattened in prepelvic region and compressed posterior, head small and depressed, mouth anterior, narrow and crescentic, maxillary barbel reaching up to pectoral fin or cross the pectoral fin, longitudinal stripes along the lateral line, eyes small, skin smooth with brownish to blackish colour, caudal deeply forked, upper lobe is twice the lower lobe, adipose dorsal fin low and extensive and much elongated attaching almost the base of upper caudal lobe differentiating from the description of other authors, branchiostegal rays 6 , dorsal with one un-branched and 5 - 6 branched rays, pectoral 5 soft rays with a serrated spine, pelvic 6 soft rays, anal with $18-21$ branched rays, and caudal with 16 - 18 principal rays (Fig.1 B).

Distribution: Rivers of the Terai and Duars, Nagaland, Arunachal, Meghalaya, West Bengal, Bangladesh, Assam-Bhutan Frontier, Mangaldai and newly recorded here from Chirang district (Langkhar, Kanamakra and Nangalbhanga hill streams) of Assam.

IUCN status: Vulnerable (VU)

Olyra Iongicaudata M cClelland, 1842

M aterial examined: Holotype: GUZM- 0139, 88 mm SL; Kanamakra hill stream (Amguri - $30 \mathrm{~km}$ north from Bijni town) in Chirang district $\left(26^{\circ} 15^{\prime} 0^{\prime \prime}-27^{\circ} 0^{\prime} 0^{\prime \prime} \mathrm{N}\right.$ and $90^{\circ} 30^{\prime}$ 0" - 9045' 0"E) of Assam, 2012

Paratypes: ZSIF 12446/1, 1, 50.0 mm SL; MUMF-14101(1), Manipur University Fishery Museum, Manipur, India; GUZM- 0140 (3), 96 mm SL- 100.80 mm SL, Langkhar, Kanamakra and Nangalbhanga hill streams (Amteka and Amguri-42 kmand $30 \mathrm{~km}$ north from Bijni town) in Chirang

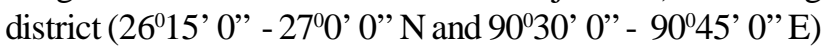
of Assam, 2012

Diagnosis: Anal fin with v, 13 rays, posterior end of adipose fin base at vertical level of posterior end of anal fin base, pelvic fin not reaching half length of distance between pelvic and anal fins, jaws of equal length, caudal fin forked and upper lobe longer than lower, almost twice as long as lower one, adipose dorsal fin short, maxillary barbels reach up to pectoral fin, maximum head width $73.91-83.33 \%$ HL, head depth at occiput $49.60-60 \%$ HL, inter-orbital space $27.02-33.33 \%$ HL, eye diameter
$8.40-12.50 \%$ HL, snout length $26.45-35.83 \%$ HL, body depth 9.72 - $11.26 \%$ SL, caudal peduncle length $14.03-$ $16.74 \%$ SL, head length 15.37 - 17.69\% SL (Table 1).

Description: Body elongated, slender, flattened in prepelvic region and compressed posterior, head small and depressed, mouth anterior, narrow and crescentic, maxillary barbel reaching up to base of pectoral fin, dorsal fin inserted in almost equidistance of pelvic fin, two or three longitudinal stripes lies along the lateral line, eyes small, skin smooth, body colour brownish, caudal deeply forked with longer upper lobe, adipose dorsal fin free and short, branchiostegal rays $5-6$. Dorsal with one unbranched and 5-6 branched rays, pectoral 5 soft rays with a serrated spine, pelvic 6 soft rays, anal with 18-23 branched rays, and caudal with 15 - 18 principal rays (Fig.1 C).

Distribution: Khasi hills of Meghalaya, Assam (newly recorded here from Kanamakra, Langkhar and Nangalbhanga hill streams in Chirang district), Nepal, and Myanmar

IUCN status: Vulnerable(VU)

\section{DISCUSSION}

As India has emerged as one of the global hot spot occupying second position in the inland fisheries sector of the world, the North East India $\left(27^{\circ} 57^{\prime}-29^{\circ} 23^{\prime} \mathrm{N}\right.$ and between $87^{\circ} 58^{\prime}-97^{\circ} 09^{\prime}$ E) constituted by eight states including Sikkim, is one of the global hot spots of faunal diversity in general and fish diversity in particular. This region forms a part of the Eastern Himalaya extending from Sikkim eastwards embracing the Darjeeling hills of northern West Bengal to Arunachal Pradesh, extending up to Mizoram in the south east corner. Extending over an area of about 2,62,230 sq.km this region embraces four drainage based systems for fish faunal diversity, namely, the Brahmaputra, the Barak-Meghna-Surama, the Kaladan and the Chindwin. The region from Bhutan foot hills in its southern margin, the Indo-Bhutan headwater occupies a special habitat diversity of fish species. The Indo-Bhutan streams flowing from Bhutan foothills through Chirang district to the Brahmaputra River in Assam comprise a number of coldwater streams of Manas river tributary namely, Burisuta, Hakoa, Kuklung, Duloni, Garawa, Rekajoli, Jiasura, Sukanjan in the eastern part and of Aie river tributary namely, Champamoti, Lopani, Dholpani, Deosri, Bordangi, Bhur, Hatisar, Langkhar, Teklai, Sukan Teklai, Buriaie, Nangalbhanga and Kanamakra, which are of special interest in the present fish diversity study.

Three species of the genus Olyra McClelland, 1842 namely Olyra longicaudata McClelland, 1842, Olyra kempi Chaudhuri, 1912 and Olyra horae (Prasad and Mukerji, 1929) are confirmed from the type localities of the studied streams in Chirang district of Assam. The 


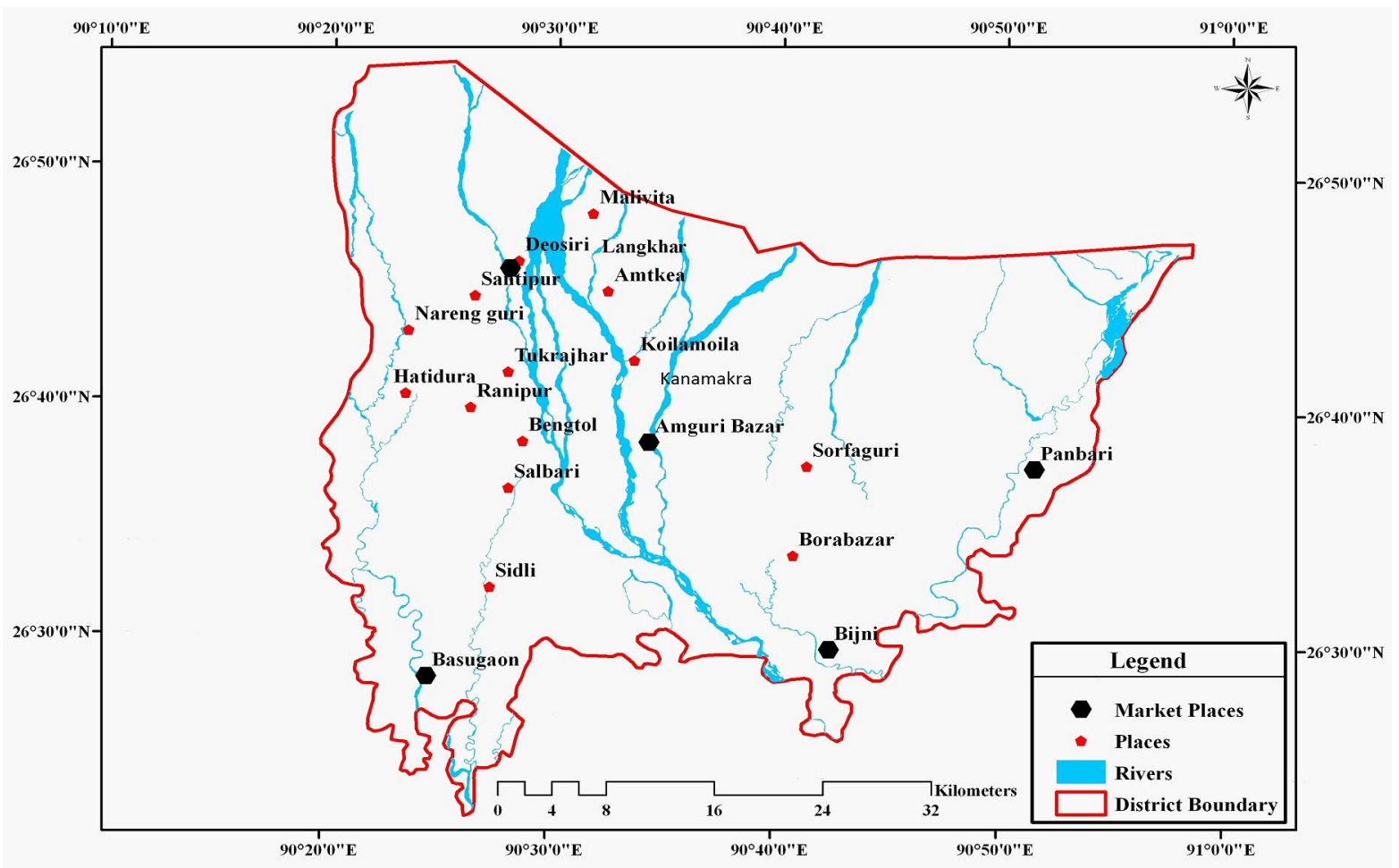

Fig. 2. Map of Chirang district of Assam, India.

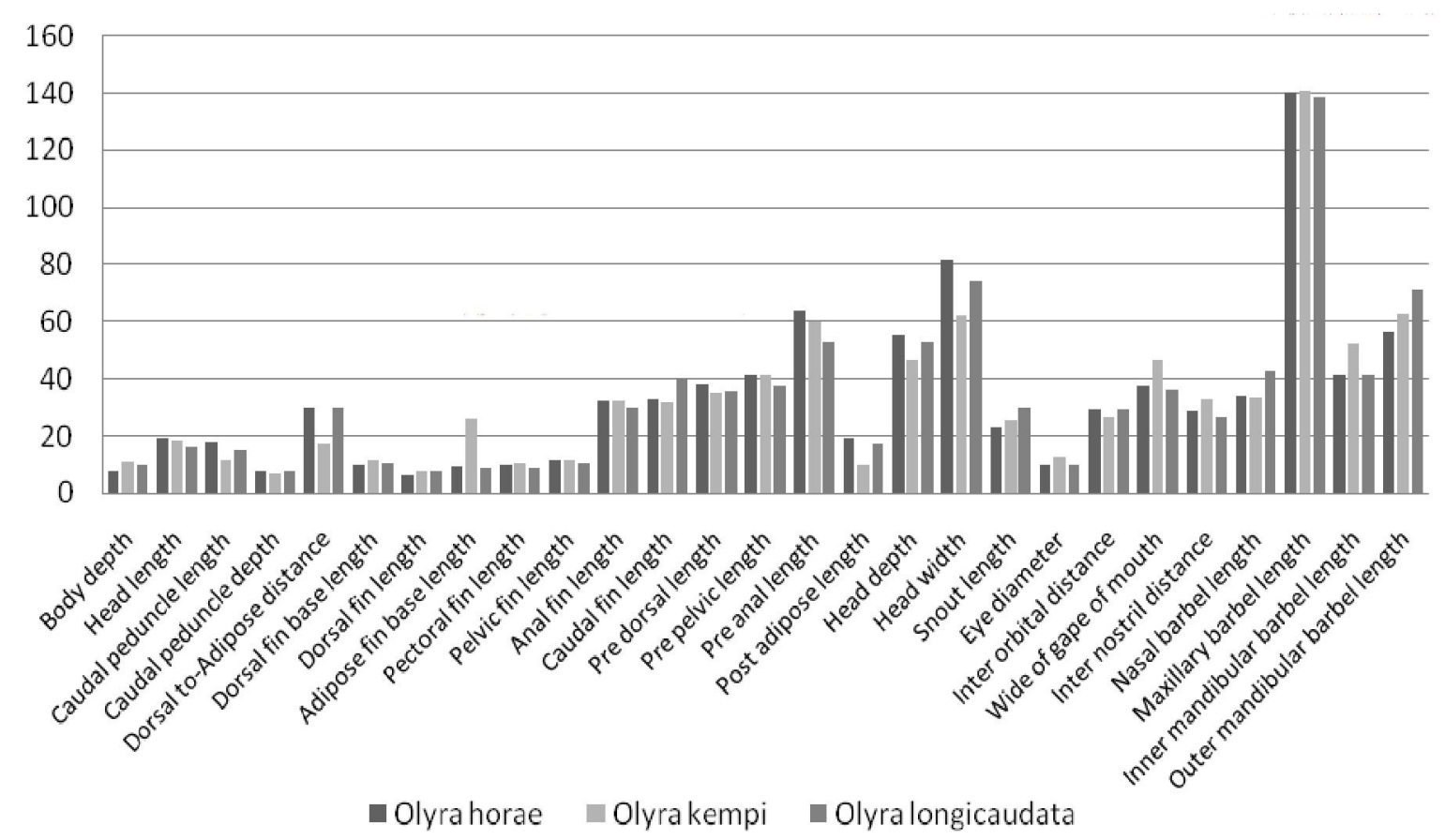

Fig. 3. Histogram showing variation of biometric characters of three species of Olyra. Body depth (BD) to Post adipose length in relation to Standard length (\% SL) and $\mathrm{H}$ ead depth to 0 uter mandibular barbel length in relation to head length (\% $\mathrm{HL}$ )

holotype specimens of Olyra longicaudata and Olyra kempi are described from both the streams. However, Olyra horae, which was not reported earlier from Assam, has been recorded from the studied type locality of Kanamakra and Langkhar streams only. Olyra horae was previously described as Ambyceps horai Prasad and Mukerji, 1929 from Indawgyi Lake along its western shore near Loimon village of Myitkyina district of upper Myanmar. Pillai and Yazdani (1972) and Ferraris (2007) also described the same species from Holotype (unique): ZSI F10854/1. However, this species was described as a valid species Olyra horae (Prasad and Mukerji, 1929). Olya kempi was reported by Chaudhuri, 1912 from Mangaldai of Assam-Bhutan Frontier of India. A further 
study on the syntype of this species was made by Ferraris (2007), which was questionably mentioned as a synonymy of Olyra longicaudata. However Talwar and Jhingran (1991) described the same species as a valid species Olyra kempi. The similar description of this species appears from the works of Burgess (1989), Rahman (1989), MO (1991), Bockmann and de Pinna (2004), Jayaram (2006) and Ferraris (2007). Again Olyra elongata, another species of the genus was previously described from Tenassenim, Myanmar (Gunther, 1883); but it was referred as a synonym of Olyra kempi Choudhuri, 1912 and later as Olyra longicaudata (Talwar and Jhingran, 1991 and Mennon, 1999). However, the species was further referred as the synonym of Olyra kempi (Burgess 1989, Rahman '1989, Bockman and de Pinna 2004).

MeClelland, 1842 described Olyra longicaudatus from Kasyah (Khasi hills) of Meghalaya of India. The species was further studied and confirmed as a valid species Olyra Iongicaudata by Burgess (1989), Talwar and Jhingran (1991), MO (1991), Sen (1985), Menon (1999), Karmakar (2000), Bockmann and de Pinna (2004), Jayaram (2006), Ferraris (2007), Patra etal. (2011). The genus O lyra therefore is represented by three species in Indian region. Beyond the Indian region the spectacular occurrence of another species of the genus, Olyra burmanica Day, 1878 reported from Pegue (Pegu) Yoma (Yomas) of Myanmar created further confusion as soon as Menon (1999) described the species as a synonym of Olyra Iongicaudata. Further the species Olyra burmanicus was described as a valid species (Burgess, 1989; Talwar and Jhingran, 1991; Bockmann and de Pinna, 2004; Jayaram, 2006; and Ferraris, 2007), while Ferraris (2007) reported eight species of the genus of which only three species are found in northeast India, the others mostly endemic to the fresh water of Myanmar.

In the present communication, the Olyra horae is described from Kanamakra, an Indo-Bhutan stream in Chirang district of Assam (Fig. 2). It differs in its biometric characters (Table 1) in having the higher range of the caudal peduncle length (16.9 - $20.0 \%$ SL), pre-anal length (60.1 - $71.4 \%$ SL), head width (81.3 - 81.6\% HL) and the lower range of snout length (21.7 - 24.3\% HL), outer mandibular barbel length $(55.7-57.3 \% \mathrm{HL})$ than the other two species. The biometric deviation of Olyra horae from the other two species is considered for separation of the species (Fig. 3). The body depth and adipose fin base length to SL\% is identical $(9.7 \%$ SL vs. $9.9 \%$ SL and 9.3 $\%$ SL vs. $8.8 \% \mathrm{SL}$ ) to Olyra longicaudata, but less than (9.7\% SL vs. $11.2 \%$ SLand $9.3 \%$ SL vs. $25.9 \%$ SL) Olyra kempi. The head length to SL\% is identical (18.9\% SL vs. $18.4 \% \mathrm{SL})$ to Olyra kempi but more than $(18.9 \% \mathrm{SL}$ vs. $16.1 \%$ SL) O lyra longicaudata. The distance of dorsal to adipose and post adipose length to SL\% is identical (29.8\% SL vs. $29.8 \%$ SL and $19.2 \%$ SL vs. $17.2 \%$ SL) to
O lyra longicaudata, but higher than $(29.8 \%$ SL vs. 17.4 $\%$ SL and $19.2 \%$ SL vs. $9.8 \%$ SL) O lyra kempi. However caudal peduncle depth, pelvic fin length, anal fin length, caudal fin length, dorsal fin base length, pre-dorsal length and pre-pelvic length to SL\% of Olyra horae is identical to Olyra kempi and Olyra longicaudata, as well as the eye diameter, inter orbital distance, wide of gape of mouth, inter nostril distance, maxillary barbel length to $\mathrm{HL} \%$ is identical to Olyra kempi and Olyra longicaudata. The nasal barbel length to HL\% is identical $(33.7 \% \mathrm{HL}$ vs. $33.3 \% \mathrm{HL})$ to Olyra kempi but less than $(33.7 \% \mathrm{HL}$ vs. $42.7 \% \mathrm{HL}$ ) Olyra longicaudata whereas inner mandibular barbel length to HL\% is identical $(41.7 \%$ HL vs. $41.6 \%$ $\mathrm{HL})$ to Olyra longicaudata but less than $(41.7 \% \mathrm{HL}$ vs. $52.4 \% \mathrm{HL}$ ) Olyra kempi. The head depth to HL\% is identical (55.5\% HL vs. $52.7 \% \mathrm{HL}$ ) to O lyra longicaudata but more than (55.5\% HL vs. $46.6 \% \mathrm{HL})$ O lyra kempi.

\section{Conclusion}

The records of the genus Olyra might be significance information to the taxonomic researchers in regards of evolutionary studies. Information of three species of Olyra from this locality would help for further investigation in concern of biodiversity conservation and the endemic status of species along with habitat conservation. The record of 0 . horae and its taxonomic studies is the major findings in this regard.

\section{ACKNOW LEDGEMENTS}

We acknowledge the help and assistance received from the SAP Aquaculture Laboratory and the Fish Biology and Fishery Science Laboratory of the Zoology Department of Gauhati University, Assam for conducting the program. We owe special thanks to Professor W. Vishwanath Singh and Y. Rameshori of the Department of Life Sciences (Zoology), Manipur University, Manipur for confirmation of the species and for providing with the paratypes specimens during their taxonomic identification.

\section{REFERENCES}

Burgess, W. E. (1989). An atlas of freshwater and marine catfishes: A preliminary survey of the Siluriformes. T. F. H. Publications, Neptune City, New Jersey, U.S.A., 154 pp.

Bockmann, F. A. and de pinna, M. C. C. (2004). Heptapterus collettii Steindachner, 1881: a member of the Asian bagrid genus Olyra erroneously assigned to the neotropical fauna. $671 \mathrm{pp}$.

Chaudhuri, B. L. (1912). Descriptions of some new species of freshwater fishes from North India, Records of the Indian M useum (Calcutta), V.7 (Pt 5):437 6444.

Day, F. (1878) The fishes of India; being a natural history of the fishes known to inhabit the seas and fresh waters of India, Burma, and Ceylon, William Dowson \& Co., London, 778 pp.

Ferraris, C.J. (2007). Checklist of catfishes, recent and fossil 
(Osteichthyes: Siluriformes), and catalogue of siluriform primary types. Zootaxa, 418: 16628 .

Gunther, A. (1883). Notes on some Indian fishes in the collection of the British Museum. Annals and Magazine of Natural H istory (Series 5) V.II (no. 62): 1376140.

Jayaram, K. C. (1999). The freshwater fishes of the Indian Region. Narendra Publishing House, Delhi, 551 pp.Jayaram, K. C. (2006). Catfishes of India. Narendra Publishing House, Delhi, pp. 93.

Karmakar, A. K. (2000). Fish communities and their distribution in Himalayan drainage system. Record of Zoological Survey of India, 98(4):25 637.

M'Clelland, J. (1842). On the Fresh water fishes collected by William Griffith, Esq., F. L. S. Madras Medical Service, during his travels under the orders of the Supreme Government of India, from 1835 to 1842 . Calcutta J ournal of Natural History, II: 5606589.

Menon, A. G. K. (1974). A checklist of fishes of the Himalayan and the Indo-G angetic plains. Special publication No. 1, Inland fisheries societies of India, 136pp.

Menon, A. G. K. (1999). Checklist- freshwater fishes of India. Records of the Zoological Survey of India, Miscellaneous Publications, Occasional Paper No.175: 1-366+i-xxviii.

Mo, T. (1991). Anatomy, relationships and Systematics of Bagridae (Teleostei:Siluroidei) with a hypothesis of Siluroid phylogeny. Thesis Zoologicae 17: 16216.

Molur, S. and Walker, S. (Eds.) (1998). Report of the Workshop "Conservation Assessment and Management Plan (CAMP) for Freshwater Fishes of India". Report \# 18, Zoo Outreach
Organisation/Conservation Breeding Specialist Group, India, Coimbatore, India, and NBFGR, Lucknow, India.

Nath, P. and Dey, S. C. (2000). Fish and Fisheries of North Eastern India (Arunachal Pradesh), Narendra Publishing House, Delhi 217 pp.

$\mathrm{Ng}, \mathrm{H}$. H. and Kottelat, M. (1998). The catfish genus Akysis Bleeker (Teleostei: Akysidae) in Indochina, with descriptions of six new species. J ournal of Natural History, 32: 105761097.

Patra, A. K., Sengupta, S., and Datta, T. (2011). PhysicoChemical properties and Ichthyofauna Diversity in Karala River, a tributary of Teesta River at Jalpaiguri district of West Bengal, India. International J ournal of Applied B iology and P harmaceutical Technology, 2 (3), 47658.

Prashad, B. and Mukerji, D. D.(1929). The fish of the Indawgyi Lake and the streams of the Myitkyina district (Upper Burma). Records of the Indian M useum, V. 31: 1616223.

Rahman, A. K. A. (1989). Freshwater Fishes of Bangladesh. The Zoological Society of Bangladesh, Dhaka, 364 pp.

Sen, T.K. (1985). The fish fauna of Assam and the neighbouring North-eastern states of India, Records of Zoological Survey of India, Occasional paper No. 64: 16216.

Talwar, P. K. and Jhingran, A. G. (1991) Inland fishes of India and adjacent countries. Oxford \& IBH Publishing Co. Pvt. Ltd., New Delhi, Bombay, Calcutta, 695pp.

Pillai, R. S. and Yazdani, G. M. 1972. First record of the catfish, Olyra horai Prashad and Mukherjee (Siluriformes: Olyridae) from Indian water with brief redescription of the species. J ournal of Zoological Society, India, 23 (2): 136. 